Eniko Korcsmaros,

Ph.D., J. Selye University, Slovakia

ORCID ID, 0000-0002-2026-8712

email: korcsmarose@ujs.sk

Renata Machova,

Ph.D., Associate Professor, J. Selye University, Slovakia

(D) ORCID ID, 0000-0002-7817-0187

email: machovar@ujs.sk

Zoltan Seben,

Ph.D., J. Selye University, Slovakia

iD ORCID ID, 0000-0002-6081-4028

email: sebenz@ujs.sk

Tibor Zsigmond,

J. Selye University, Slovakia

ORCID ID, 0000-0002-2581-5519

email: zsigmond.tibor@student.ujs.sk

Correspondence author: machovar@ujs.sk

\title{
THE REGIONAL INNOVATIONS GOVERNANCE: SLOVAKIA WITH REGARD TO CONVERGENCE CRITERIA
}

Abstract. The introduction of the euro in Europe is subject to several criteria. In 1979, the European Community created the «European Exchange Rate Mechanism» (ERM). On 16 April, 2003, Slovakia, together with nine other countries, signed the EU Accession Treaty in Athens. These countries promised to adopt the single currency (the euro). It has been 10 years since the introduction of the euro in Slovakia. It stands to highlight factors that have contributed to the economic, innovation development experienced in recent years regarding introducing a single currency. This article aims to briefly introduce the euro area and present each country's accession in historical order. the authors presented the general conditions for introducing the euro and then went on to the events related to the regional innovations governance of Slovakia. Using the data from the statistical site Eurostat, the Pearson correlation coefficient was used to indicate the closeness of relationships between the average values of inflation and government deficit and the average values of inflation and the public debt. The limitations of the research are that Eurostat's values are only indicative and, in the event of a possible accession, EU bodies would certainly use other, more reliable data. Furthermore, the ERM II criterion for joining the euro area cannot be examined due lack of statistics available on the Slovak koruna's value after the introduction. Another limitation is that the EU sometimes makes adjustments to calculating inflation and average nominal long-term interest rates. There is a lack of a significant relationship between the examined variables in the case of Slovakia. Based on the 2018 inflation rate, the introduction would not have been possible, as it was slightly higher (2.5 per cent) than the limit (2.23 per cent). Therefore, the authors assumed that Slovakia had adopted the euro on time, as if it had not done so on 1 January 2009, it would probably have had to wait a few years for the new opportunity. Although their results are only indicative and not decisive without taking ERM II into account, it is possible to do without specific indicators.

Keywords: innovative development, Slovakia, single currency, inflation rate, government deficit, public debt.

Cite as: Korcsmaros, E., Machova, R., Seben, Z., \& Zsigmond, T. (2021). The Regional Innovations Governance: Slovakia with Regard to Convergence Criteria. Marketing and Management of Innovations, 1, 170-180. http://doi.org/10.21272/mmi.2021.1-13 
Introduction. It is now 20 years since the euro was introduced in 11 countries (Belgium, Luxembourg, Germany, Spain, France, Ireland, Italy, Netherlands, Austria, Portugal, Finland). In contrast, in 4 EU Member States (Denmark, UK, Sweden, Greece), it was not introduced. A further 3 countries (Monaco, San Marino and the Vatican) have also been authorized to use the euro. These countries used to use the currencies (French franc and Italian lira) traded in France and Italy, so they switched to the euro after they ceased to exist. They were also allowed to have their own national symbols on each coin. The case of Andorra is also interesting, as the country had no official currency until 2012. French francs and Spanish pesetas were used before the euro. The country did not make a deal with the EU. Initially, it did not issue coins with its own design, although the euro was being used in the country. Later, they began negotiations with the EU and agreed that, from July 2013, the state would issue its own model coins. The introduction date has been postponed several times, until finally, on 15 January 2015, the use of self-minted coins in the country began (Bielik, 2010; European Central Bank, 2021; European Commission, 2011; European Commission, 2014b; Vovchak et al., 2018; Baranovskyi, 2018; Dzwigol \& Wolniak 2018; Harust et al., 2019; Zestos and Benedict, 2018).

Later, Greece (2001) introduced the euro. A further 10 countries (Hungary, Cyprus, Czech Republic, Estonia, Latvia, Lithuania, Malta, Poland, Slovakia and Slovenia) joined the EU in May 2004, and in 2007 two more (Bulgaria and Romania) joined the European Union and agreed with the proviso that the euro will be introduced in their own countries in the future. Slovenia (2007), Cyprus (2008) and Malta (2008) did this, and on the 10th anniversary of the international introduction of the euro, on 1 January 2009, Slovakia also became the legal tender. That was an event of great importance for the country since it existed in this completely independent form only since 1993. In turn, that overtook countries such as Estonia, Latvia and Lithuania, where the euro was introduced later (2011, 2014 and 2015). It has also overtaken other V4 countries - Hungary, Poland and the Czech Republic - which have not yet adopted the euro. Most recently (2013), Croatia joined the European Union. It is also interesting to mention the cases of Montenegro and Kosovo, which are also using the euro, even though neither of them has an agreement with the EU (European Central Bank, 2021; European Commission, n.d.; European Commission, 2013; European Commission, 2014b; Zestos and Benedict, 2018).

Thus, according to the above, now 19 countries are members of the euro area, while 4 countries using the euro as their currency and 2 without contracts. The euro is the legal tender in the Member States but not in Europe. That includes countries and territories such as French Guiana, Guadeloupe, Martinique, Reunion, Melilla, Ceuta, Azores, Canary Islands, Madeira, Saint Pierre and Miquelon, Mayotte, Saint-Barthelemy, Saint-Martin, Clipperton Island and French Indian Ocean Islands. The exceptions are New Caledonia, French Polynesia, Wallis and Futuna, Aruba, Curacao, Sint Maarten, Caribbean Netherlands (Bonaire, Sint Eustatius and Saba), Northern Cyprus and Campione d'Italia, which use currencies other than the euro for various reasons (European Central Bank, 2021; European Commission, 2014b; Zestos and Benedict, 2018).

There are currently 27 Member States of the European Union after Brexit. Andorra, Iceland, Lichtenstein, Monaco, Norway, San Marino, Switzerland and the Vatican are not member states, but they have various agreements with the EU. The EU currently has 5 candidate countries: Turkey (since 1987), Northern Macedonia (2004), Montenegro (2008), Albania (2009) and Serbia (2009). Turkey's different views with the EU have led to a reduction in accession chances in recent years. Iceland submitted its application for accession in 2009, which led to the opening of negotiations in 2010. In 2013, a new government was formed in the country, which suspended negotiations with the EU, and in 2015 withdrew its membership application. Bosnia and Herzegovina and Kosovo are considered to be the potential candidates (European Commission, n.d.; European Commission, 2013; European Commission, 2017). 
Denmark and Sweden neither plan to adopt the euro in the future. Denmark is not obliged by the EU to adopt the euro, which is also enshrined in the Treaty. For these countries, only parliamentary votes or referendums could change the situation. In Sweden, in a referendum in 2003, joining the eurozone was voted down, so they cannot be counted on at the moment. The remaining countries (the Czech Republic, Hungary, Poland, Romania, Bulgaria, Croatia) undertook introducing the euro upon accession, but no significant progress has been made. Various «predictions» have been made in these countries regarding the future of the introduction. In 2001, the MNB (2001) planned to introduce the euro in Hungary by 2006, but the central bank's Governor considered 2007 more likely. In 2002 Viktor Orban had already announced the 2008 date in his campaign, as did Peter Medgyessy. However, in 2005 it was already a 2010 launch and was planned for the 2011-2013 timeline. In 2009, Ferenc Gyurcsany, Prime Minister of Hungary, has already stated that the euro will certainly not be introduced in Hungary before 2012. Gordon Bajnai then designated 2014, while Viktor Orban considered 2015 more likely. In 2010, there was talk of a 2019 launch, but that hasn't happened and is not expected to happen soon.

In Poland, in 2010, the euro could be introduced at the earliest by 2019. The Czechs then counted on a 2020 date. None of these goals has been achieved. Romania, which joined in 2007, plans to introduce the euro by 2020 , while Bulgaria has stated that it does not want to join the zone for the time being because it would not bring too many benefits for the country. As Croatia only joined in 2013, no major change is expected soon either. Even though all countries have committed themselves to the introduction of the euro at the time of their accession to the EU, individual regulators do not 'urge' or oblige individual countries to keep the promise (Belas et al., 2019; European Commission, 2014b; Jenei, 2010; Mihalcova et al., 2020; MTI-Eco, 2011; Origo, 2012; Privatbankar, 2013; Zestos and Benedict, 2018).

It may be worth examining past events and changes. Therefore, this article deals with Slovakia and its events and impacts before and after introducing the euro. It is important to understand these past events and then investigate Slovak economic indicators' changes after 2008, making the Euro introduction possible in the country.

The theoretical part describes the general requirements for countries that want to adopt the euro as the official currency. It also presents the adaptation process of the euro in Slovakia. The research is based on secondary data to investigate if Slovakia had met the criteria defined in the Maastricht Treaty after 2008. The next part contains the results of this research. Each of the criteria (government deficit, public debt, inflation rate, nominal long-term interest) are examined one by one, and there is a summary at the end of this study. Based on the results, the study summarizes the main conclusions.

Literature Review. The introduction of the euro in Europe is subject to several criteria. In 1979, the European Community created the «European Exchange Rate Mechanism», which in short is called the ERM from the initials of the English name. It is part of the «European Monetary System» created to establish the «Economic and Monetary Union». In particular, it aims to reduce exchange rate fluctuations and to create financial stability in the Community. On 31 December 1998, individual ECU exchange rates were frozen in the 11 countries that adopted the euro. The next day (1 January 1999), the euro became the legal tender in the countries listed above. The ECU («European Currency Unit») is the European Community's currency, later of the European Union. It did not exist in physical form. It was created to compare the currencies of individual member states easier and mitigate the fluctuations between them. The ECU existed from 1979 until 1999. For each Member State, the exchange rate is fixed every five years. Countries could only deviate by 2.25 per cent. Italy was the only exception, with a $6 \%$ tolerance (Bacik et al., 2019; Council of the European Communities, 1992; EUR-Lex, 2006; European Central Bank, 2021; Gavurova et al., 2017; Papaspyrou, 2004; Verbeken and Rakic, 2019).

After the introduction of the euro, its value was fixed at a rate of 1 to 1 . Despite this, the ERM has not ceased to exist but still survived with little change. The system was called ERM II. Now the euro has 
become the benchmark. Another change was that in the case of a country wishing to join the euro area, the currency's value could fluctuate within the $15 \%$ range of the central rate (which could be changed in the meantime). That applies to both negative and positive movements. The agreement reads: «... ERM II will help ensure that non-euro area Member States participating in ERM II orient their policies towards stability, support convergence and thus contribute to the efforts of those Member States to adopt the euro». Further assistance is provided by the European Central Bank, which provides a short-term support framework for countries that meet the criteria and wish to join, but for some reason, need to protect the exchange rate band. The conditions for this are agreed in advance with the countries concerned (Council of the European Communities, 1992; EUR-Lex, 2006; Helísek, 2019; Papaspyrou, 2004).

At the time of ERM II, only two Member States were involved (Greece and Denmark). Greece introduced the euro in 2001, but Denmark remains a member and has agreed to keep the Danish krone in the 2.25 per cent band compared to the euro. That was much stricter than the 15 per cent band, but the Danes could easily keep it. Later (2004 and 2007), new countries joined the EU. In turn, it set a band of 2.25 per cent, but the EU allowed the appreciation of certain currencies so that only the weakening was concerned (Council of the European Communities, 1992; EUR-Lex, 2006; NBS; Verbeken and Rakic, 2019).

However, joining the euro area is not merely linked to ERM II. Members have to meet additional criteria, known as "convergence criteria». The term «Maastricht criteria» is also known since the contract summarizing the specifications was concluded in Maastricht in 1992. According to the CSO, these criteria are as follows:

The general government deficit is less than $3 \%$ of GDP.

Inflation may be up to 1.5 percentage points higher than the three Member States' average with the lowest rates.

The average nominal long-term interest rate may be up to 2 percentage points higher than the three Member States' average with the lowest inflation rates.

Ensure the national currency's stability for two years (compliance to ERM II exchange rate band) (Kljucnikov et al., 2016, 2020; Papaspyrou, 2004; Polasek and Amplatz, 2003).

So all of the above must be fulfilled by the country that wants to join. In the following, the paper examines the past of Slovakia concerning the data known.

Slovakia started preparations for the introduction of the euro before its accession to the European Union. On 16 April 2003, Slovakia and nine other countries signed the EU Accession Treaty in Athens. They also promised to adopt the single currency (the euro). It adopted a specific strategy initiated by the Slovak State to determine the euro's introduction and the tasks to be performed in this regard. The state has taken further measures and in 2005 also set up a single national plan for the introduction of the euro. This plan was updated, improved and supplemented in 2007 and 2008. On 28 November 2005, the Slovak koruna became part of ERM II (European Exchange Rate Mechanism). At that time, 1 EUR was converted to SKK at the exchange rate of 38,455 . The state first entrusted economist Ivan Stefanec and then Igor Barat with the task of introducing the euro. In March 2007, at the Slovak State's request, the European authorities revaluated the exchange rate to the value of 1 EUR $=35,442$ Slovak koruna. The lower limit of the associated 15 per cent band was then SKK 30,126, and the upper was SKK 40.759. In 2007, Slovakia also introduced a new law promoting the introduction of the euro (under the original Slovak title: «Zakon c. 659/2007 Z. z.o zavedení meny euro v Slovenskej republike a o zmene a doplnení niektorých zakonov»).

On 1 April 2008, the National Bank of Slovakia announced its plan to withdraw the Slovak crown. On 29 May 2008, the Ministers of Finance of the euro area countries and the European Central Bank and the central banks of Denmark, Estonia, Lithuania, Latvia and Slovakia re-evaluated the exchange rate. 
At that time, the exchange rate was set at 1 euro $=30.126$ Slovak koruna. The lower limit was SKK 25.6071, and the upper limit was SKK 34.6449. On 3 June 2008, the EU Member States' meeting, the Economic and Financial Affairs Council (ECOFIN), recommended the date of 1 January 2019 to introduce the Slovak euro. On 8 July 2008, the European Council set an irrevocable conversion value of EUR $1=30.126$ Slovak koruna. As of August 2008, prices should now be displayed by trade units in Slovak koruna and euro. They were obliged to do so until 31 December 2009. Besides that month (19 August 2008), the official Slovak euro coins' mintage in Kremnica (Kremnica) was started. These were being sold since 1 December 2008 in so-called starter packs (or kits).

Of course, the country also fulfilled the other convergence criteria mentioned above, and finally, on 1 January 2009, the euro was successfully introduced in Slovakia. Until 16 January 2009, people could pay for their products and services in euros and crowns, but sellers could only give the change back in euros. Slovak coins were accepted by commercial banks until 30 June 2009, banknotes until 31 December 2009, and the National Bank of Slovakia accepted coins until 2 January 2014. Banknotes are still being redeemed by the NBS (JurciSinova, 2012; Korcsmaros et al., 2018; Machova and Veghova, 2013; NBS; Rajnoha et al., 2018).

The introduction of the euro has brought many benefits, but there have certainly been some disadvantages. Some of these are economic, financial and social. However, this article does not aim to further investigate these effects.

Methodology and research methods. The first part of this article provides a brief introduction to the euro area. The accession of each country was presented in chronological order. It presented the general conditions for introducing the euro and then went on to the events related to the introduction of Slovakia. The preparation of these chapters mainly relied on Slovak and Hungarian literature. The second half of this article presented the changes (that have occurred since its introduction). Within this, the study only deals with the criteria attached to introducing the euro and its values after the introduction. The secondary research obtained data (inflation rate, average nominal long-term interest rate, government deficit, and government debt) from Eurostat databases.

To examine the closeness of the data, the Pearson correlation coefficient (r), has been chosen, which could be determined:

$$
r=\frac{\sum_{i=1}^{N}\left(x_{i}-\underline{x}\right)\left(y_{i}-\underline{y}\right)}{\sqrt{\sum_{i=1}^{N}\left(x_{i}-\underline{x}\right)^{2} \sum_{i=1}^{N}\left(y_{i}-\underline{y}\right)}}
$$

where $\underline{x}$ is the mean of $x_{i}$ and $\underline{y}$ is the mean of $\mathrm{yi}_{\mathrm{i}}$ The value of the correlation coefficient could range from -1 to +1 , where the absolute value of the pointer indicates the closeness of the relationships and its sign indicates the intensity of the relationship.

The limitations of the research are that Eurostat's values are only indicative. Besides, in a possible accession, EU bodies would certainly use other, more reliable data. Furthermore, the ERM II criterion for joining the euro area cannot be examined as there are no statistics available on the Slovak koruna's value after the introduction, only some assumptions. Another limitation is that the EU sometimes makes adjustments to calculating inflation and average nominal long-term interest rates. For example, if outliers are generated, in some cases, they are corrected. Such was the 2014 survey, which did not consider the inflation rates of Greece, Bulgaria and Cyprus, which were only outstanding due to local exceptional economic measures. For the sake of simplicity, the researchers of this paper do not consider these details in this article (Bilan et al., 2019; 2020; European Commission, 2014a).

Results. Below, the study examines Slovakia in terms of the "deficit criterion», i.e. the general government deficit for the last 10 years, starting with 2008, which was important for the introduction in 
E., Korcsmaros, R., Machova, Z., Seben, T., Zsigmond. The Regional Innovations Governance: Slovakia with Regard to Convergence Criteria

2009. The results have been obtained with Eurostat's help, while the Maastricht Treaty sets the $3 \%$ deficit limit concerning GDP. The following graph illustrates the general government deficit in Slovakia. The values are in percentages.

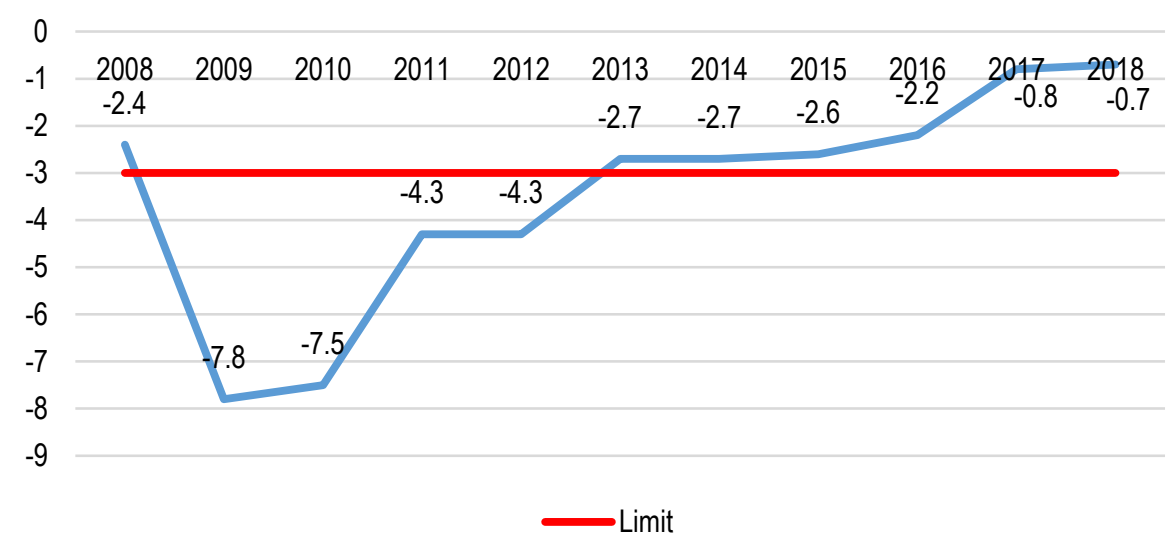

Figure 1. General government deficit in Slovakia over the last 10 years

Sources: developed by the authors based on (Eurostat, 2019a).

Figure 1 shows that Slovakia fulfilled this criterion in 2008. However, then it performed below the limit, respectively. It is believed that this phenomenon is due to the global crisis. It is also evident that the deficit has fallen below 3 per cent from 2013 onwards and increased due to the minus sign. Government finances are gradually declining so that the deficit figures are of increasing value as interpreted by Eurostat. Thus, based on the data of recent years, positive results could be reported.

The next important criterion is public debt, which should not exceed $60 \%$ of GDP. This criterion is considered in conjunction with the general government deficit. The research also started with 2008, and 2018 was the last year for consideration, as this is the last year to be considered fully completed. Based on the data, the following graph 2 was obtained.

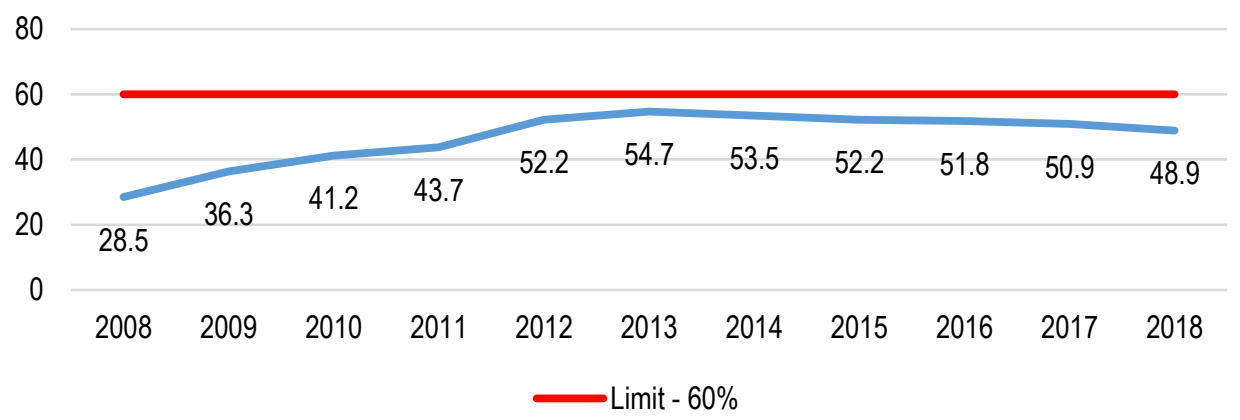

Figure 2. Public debt levels in Slovakia over the past 10 years

Sources: developed by the authors based on (Eurostat, 2019b). 
The data clearly show that the government debt level was the lowest before the introduction (28.5 $\%$ ). Debt has gradually increased in the following years, but after 2013 , there is again a downward trend in the indicator. On the positive side, Slovakia has met this criterion in each of the last 10 years. That is also remarkable because, apart from Slovakia, only 4 Member States (Estonia, Lithuania, Latvia and Luxembourg) with the euro were able to meet the $60 \%$ threshold in each of the last 10 years (Eurostat, 2019b).

The next criterion is inflation. On this basis, inflation may be up to 1.5 percentage points above the three Member States' average with the lowest rates. To calculate this, the 3 lowest inflation rates for each year have been selected. Then, an average of these 3 rates each year have been subtracted, and finally added 1.5 percentage points to each of the annual averages, as the criterion requires.

Table 1. Minimum inflation rates for each year and year values based on this criterion over the past 10 years, based on EU Member States

\begin{tabular}{lccccccccccc}
\hline & $\mathbf{2 0 0 8}$ & $\mathbf{2 0 0 9}$ & $\mathbf{2 0 1 0}$ & $\mathbf{2 0 1 1}$ & $\mathbf{2 0 1 2}$ & $\mathbf{2 0 1 3}$ & $\mathbf{2 0 1 4}$ & $\mathbf{2 0 1 5}$ & $\mathbf{2 0 1 6}$ & $\mathbf{2 0 1 7}$ & $\mathbf{2 0 1 8}$ \\
\hline 1st lowest & 2,2 & $-1,7$ & $-1,6$ & 2,1 & 1,9 & 0,4 & $-1,6$ & $-1,5$ & $-1,3$ & 0,3 & 0,7 \\
2nd lowest & 2,7 & $-0,9$ & $-1,2$ & 1,4 & 1 & 0,4 & $-1,4$ & $-1,1$ & $-1,2$ & 0,7 & 0,7 \\
3rd lowest & 2,8 & $-0,2$ & 0,7 & 1,2 & 0,9 & 0 & $-0,3$ & $-0,8$ & $-1,1$ & 0,8 & 0,8 \\
Average & 2,6 & $-0,9$ & $-0,7$ & 1,6 & 1,3 & 0,3 & $-1,1$ & $-1,1$ & $-1,2$ & 0,6 & 0,7 \\
Criterion & 4,1 & 0,6 & 0,8 & 3,1 & 2,8 & 1,8 & 0,4 & 0,4 & 0,3 & 2,1 & 2,2 \\
(average +1,5) & & & & & &
\end{tabular}

Sources: developed by the authors based on (Eurostat, 2019c).

The average values of inflation were examined jointly in light of the evolution of the general government deficit and the public debt. The comparison and analysis were performed by statistical calculation. The tightness of the relationship between the variables and the relationship's strength and intensity were determined by correlation calculation. Still, the paper first investigates whether there is a significant relationship between the examined variables. The level of significance was set at $5 \%$. Based on the average value of inflation and our hypothesis $\mathrm{HO}$ regarding the general government deficit, there is no significant correlation between the two variables examined. Similarly, at a significance level of $5 \%$, there is no significant relationship between the two variables according to hypothesis $\mathrm{H} 0$ concerning the average value of inflation and public debt value.

Table 2. Examination of the Pearsons correlation coefficient between variables

\begin{tabular}{llccc}
\hline & & $\begin{array}{c}\text { Average values } \\
\text { of inflation }\end{array}$ & $\begin{array}{c}\text { General goverment } \\
\text { deficit }\end{array}$ & Public debt \\
\hline Average values of & Pearson Correlation & 1 & 0,246 & $-0,417$ \\
inflation & Sig. (2-tailed) & & 0,467 & 0,202 \\
General & Pearson Correlation & 0,246 & 1 & 0,434 \\
goverment deficit & Sig. (2-tailed) & 0,467 & & 0,183 \\
Public debt & Pearson Correlation & $-0,417$ & 0,434 & 1 \\
\hline
\end{tabular}

Sources: developed by the authors using SPSS software.

Table 2 demonstrates the summary results of the analysis. Primarily, the evolution of significance values has been examined. Thus, it could be stated that between the general government deficit and the average value of inflation and between the public debt and the average value of inflation, the research obtained an above significance level; that there was no significant relationship between the sham pairs tested. That is also confirmed by the evolution of the Pearson correlation coefficient's value, whose absolute value indicates a weak relationship between the pairs of variables examined. 
E., Korcsmaros, R., Machova, Z., Seben, T., Zsigmond. The Regional Innovations Governance: Slovakia with Regard to Convergence Criteria

Based on the criteria for each year, it could be compared with Slovakia's results (Figure 3).

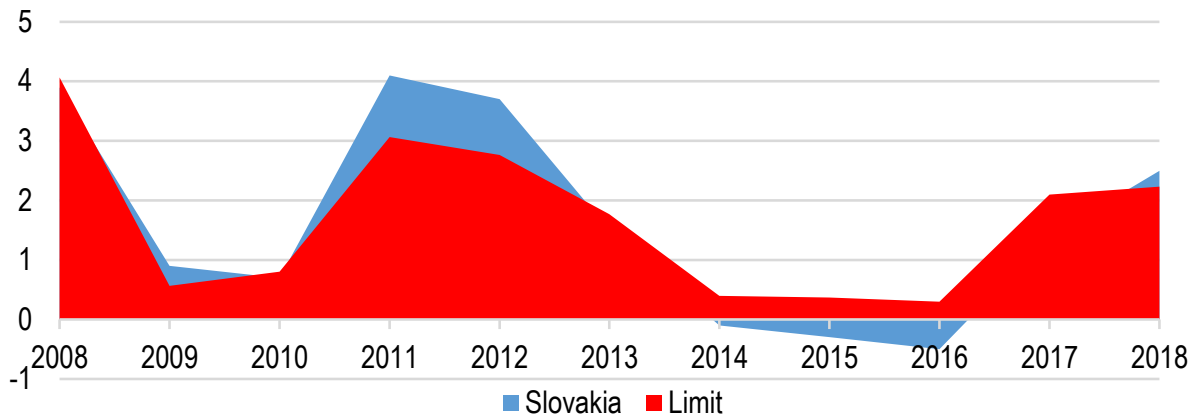

Figure 3. Inflation rate in Slovakia and threshold over the last 10 years

Sources: developed by the authors on the basis of (Eurostat, 2019c).

Specific values are omitted in the case for greater clarity of the graph, but it would be included at the end of this article. On this basis, it could be seen that the rate of inflation in 2009, 2011 and 2012 exceeded the limit of the given year. Therefore, Slovakia would not have fulfilled the Maastricht criteria for inflation in these years. In 2014, 2015 and 2016, Slovakia's inflation rate was negative, meaning deflation. In 2018, there again seemed to be a smaller difference, so this year, no country would have met the criterion.

The fourth criterion, examined by the research, is related to the average nominal long-term interest rate.

Table 3. Minimum values of the average nominal long-term interest rate, respectively. Values based on this criterion over the past 10 years, based on the EU Member States

\begin{tabular}{cccccccccccc}
\hline & $\mathbf{2 0 0 8}$ & $\mathbf{2 0 0 9}$ & $\mathbf{2 0 1 0}$ & $\mathbf{2 0 1 1}$ & $\mathbf{2 0 1 2}$ & $\mathbf{2 0 1 3}$ & $\mathbf{2 0 1 4}$ & $\mathbf{2 0 1 5}$ & $\mathbf{2 0 1 6}$ & $\mathbf{2 0 1 7}$ & $\mathbf{2 0 1 8}$ \\
\hline 1st lowest & 3,98 & 3,98 & 3,87 & 2,61 & 1,59 & 2,12 & 3,35 & 1,71 & 2,27 & 0,55 & 0,45 \\
2nd lowest & 4,23 & 4,21 & 5,74 & 4,97 & 6,17 & 3,34 & 6 & 2,49 & 3,32 & 0,8 & 0,95 \\
3rd lowest & 4,52 & 5,23 & 10,34 & 9,6 & 22,5 & 3,47 & 6,93 & 9,67 & 3,77 & 2,62 & 2,18 \\
Average & 4,2 & 4,5 & 6,7 & 5,7 & 10,1 & 3,0 & 5,4 & 4,6 & 3,1 & 1,3 & 1,2 \\
Criterion & 6,2 & 6,5 & 8,7 & 7,7 & 12,1 & 5,0 & 7,4 & 6,6 & 5,1 & 3,3 & 3,2 \\
(average +2) & & & & & & &
\end{tabular}

Sources: developed by the authors based on (Eurostat, 2019d).

For this criterion, it has been defined that the value of this rate may be up to 2 percentage points above the average of the three Member States with the lowest inflation rates. Therefore, the long-term interest rates of the countries with the lowest inflation rates examined above have been taken into account. The long term, in this case, is 10 years.

That gives the limits for each year. Then, only the Slovak values were needed for the research (Fig. 4).

Slovakia would have met the criterion of an average nominal long-term interest rate each year. That is definitely positive.

Table 4. Slovakia in relation to the four criteria

\begin{tabular}{cccccccccccc}
\hline Slovakia & 2008 & 2009 & 2010 & 2011 & 2012 & 2013 & 2014 & 2015 & 2016 & 2017 & 2018 \\
\hline Deficit (\%) & $-2,4$ & $-7,8$ & $-7,5$ & $-4,3$ & $-4,3$ & $-2,7$ & $-2,7$ & $-2,6$ & $-2,2$ & $-0,8$ & $-0,7$ \\
\hline
\end{tabular}


E., Korcsmaros, R., Machova, Z., Seben, T., Zsigmond. The Regional Innovations Governance: Slovakia with Regard to Convergence Criteria

\begin{tabular}{|c|c|c|c|c|c|c|c|c|c|c|c|}
\hline & & & & & & & & & \multicolumn{3}{|c|}{ Continued Table 4} \\
\hline Public debt (\%) & 28,5 & 36,3 & 41,2 & 43,7 & 52,2 & 54,7 & 53,5 & 52,2 & 51,8 & 50,9 & 48,9 \\
\hline Inflation (\%) & 3,9 & 0,9 & 0,7 & 4,1 & 3,7 & 1,5 & $-0,1$ & $-0,3$ & $-0,5$ & 1,4 & 2,5 \\
\hline $\begin{array}{c}\text { Average } \\
\text { nominal long- } \\
\text { term interest } \\
\text { rate }(\%)\end{array}$ & 4,72 & 4,71 & 3,87 & 4,45 & 4,55 & 3,19 & 2,07 & 0,89 & 0,54 & 0,92 & 0,89 \\
\hline
\end{tabular}

Sources: developed by the authors based on (Eurostat, 2019a; b; c; d).

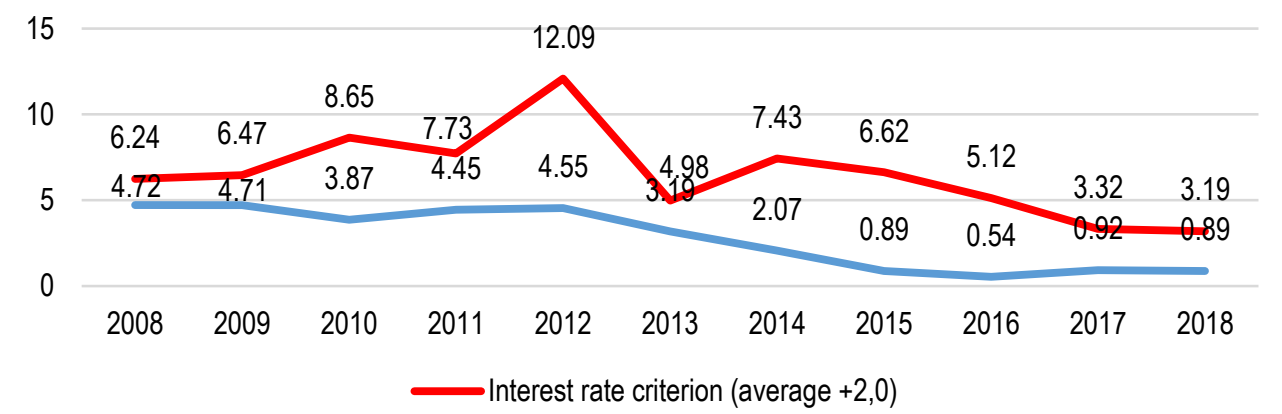

Figure 4. The average nominal long-term interest rate in Slovakia and threshold over the past 10 years

Sources: developed by the authors on the basis of (Eurostat, 2019d).

Table 4 shows Slovakia's general government deficit, government debt, inflation and average nominal long-term interest rates. The values that correspond to the given criteria in the given years are marked in green.

Conclusions. The findings clearly show that the results for 2008 met the criteria. Thus, the euro was successfully introduced in 2009. The obtained results showed that the introduction of the euro would not have been possible in the future, as in 2009, 2010, 2011 and 2012, there was 1, and in several cases, there were 2 such results. Therefore, the country would not meet the Maastricht criteria. It is believed that this is due to the impact of the global economic crisis. However, since 2013, there has been a steady improvement in most indicators. Thus, the euro could have been introduced by 2018 .

Based on the 2018 inflation rate, the introduction would not have been possible, as it was slightly higher $(2.5 \%)$ than the limit $(2.23 \%)$. Therefore, it is believed that Slovakia has adopted the euro on time. If it had not done on 1 January 2009, it would probably have had to wait a few years for the new opportunity. Of course, the results are only indicative and not decisive without taking ERM II into account, but it cannot be done without specific indicators.

Author Contributions: The authors E. K., R. M., Z. S. and T. Zs. equally contributed to the measurement, planning and supervision of the work, the implementation of the research, the analysis of the results and the writing of the manuscript. All authors have read and approved the final manuscript.

Acknowledgement: This work was supported by Pallas Athene Domus Foundation, grant number PADE-0117/4.

This research was supported by the Collegium Talentum 2019/20Programme of Hungary. 


\section{References}

Bacik, R., Kloudova, J., Gonos, J., \& Ivankova, V. (2019). Management of Competitiveness and Economic Performance Based in the V4 countries. Marketing and Management of Innovations, 3, 73-88. [Google Scholar] [CrossRef]

Baranovskyi, O. I. (2018). Quality of the transformational processes in the financial sector of the national economy: vectors of the measurement. Financial and credit activity: problems of theory and practice, 3(26), 350-367. [Google Scholar] [CrossRef]

Belas, J., Kocisova, K., \& Gavurova, B. (2019). Determinants of Cost Efficincy: Evidence from Banking Sectors in EU Countires. Acta Polytechnica Hungarica, 15(5), 101-123. [Google Scholar] [CrossRef]

Bielik, P. (2010). Economics, Social Policy and Citizenship in the European Union--evidence of V4 Countries and Perspectives for Ukraine. Visegrad Fund. [Google Scholar]

Bilan, Y., Mishchuk, H., Roshchyk, I., \& Kmecova, I. (2020). An Analysis of Intellecutal Potential and its Impact on the Social and Economic Development of European Countries. Journal of Competitiveness, 12(1), 22-38. [Google Scholar] [CrossRef]

Bilan, Y., Rubanov, P., Vasylieva, T., \& Lyeonov, S. (2019). The Influence of Industry 4.0 on Financial Services: Determinants of Alternative Finance Development. Polish Journal of Management Studies, 19(1), 70-93. [Google Scholar] [CrossRef]

Dzwigol, H., \& Wolniak, R. (2018). Controlling w procesie zarządzania chemicznym przedsiębiorstwem produkcyjnym [Controlling in the management process of a chemical industry production company]. Przemysl Chemiczny, 97(7), 1114-1116. [CrossRef]

EUR-Lex. (2006). Document 32006X0325(01). Megallapodas (2006. marcius 16.) az Európai Központi Bank es az euroövezeten kívüli tagallamok nemzeti központi bankjai között a gazdasagi es monetaris unió harmadik szakaszaban az arfolyam-mechanizmus eljarasi szabalyainak meghatarozasaról.. Retrieved from [Link]

European Central Bank. (2021). Economic and Monetary Union (EMU). Retrieved from [Link]

European Commission (2014a). Convergence Report 2014. Retrieved from [Link]

European Commission .(2013). European integration and enlargement of the European Union. Retrieved from [Link]

European Commission. (2011). Monetary Agreement between the European Union and the Principality of Andorra. Retrieved from [Link]

European Commission. (2014b). Economic and monetary union and the euro. Luxembourg: Publication Office of the European Union. Retrieved from [Link] [Link]

European Commission. (2017). European Neighbourhood Policy and Enlargement Negotiations. Iceland. Retrieved from

European Commission. (n.d.) EU ENLARGEMENT FACTSHEET. Retrieved from [Link]

Eurostat (2019c). HICP - inflation rate. Annual average rate of change (\%). Retrieved 15 May, 2020. Retrieved from [Link

Eurostat (2019d). EMU convergence criterion series - annual data. Retrieved from [Link]

Eurostat. (2019a). General government deficit (-) and surplus (+) - annual data. Retrieved from [Link

Eurostat. (2019b). General government gross debt - annual data. Retrieved from [Link]

Gavurova, B., Belas, J., Kocisova, K., Dapkus, R., \& Bartkute, R. (2017). Revenue and Cost Efficiency of Banking Sectors in The European Union Countries: Do They Depend on Size, Location or Crisis Period?. Transformations in business \& economics, 16(2). [Google Scholar]

Harust, Yu., Melnyk, V. Palienko, M., \& Prasol, L. (2019). Economic Security of the Country: Marketing, Institutional and

Political Determinants. Marketing and Management of Innovations, 4, 373-382. [Google Scholar] [Cross Ref]

Helisek, M. (2019). Exchange Rate Mechanism II and the Risk of Currency Crisis - Empiricism and Theory. Journal of International Studies, 12(1), 297-312. [Google Scholar] [CrossRef]

Jenei, M. (2010). Egyre tavolabb a magyar eurótól. Retrieved from [Link]

JurciSinova, A. (2012). Zavedenie eura na Slovensku. 8. Studentska vedecka konferencia. Zborník plných príspevkov, 743 -

755. [Google Scholar]

Kljucnikov, A., Belas, J., \& Smrcka, L. (2016). The Role of Risk-taking and Competitive Aggressiveness in Management of SMEs. Polish Journal of Management Studies, 14(1), 129-139. [Google Scholar] [CrossRef]

Kljucnikov, A., Civelek, M., Krajcik, V., \& Kmeco, L. (2020). Innovations in Tourism Marketing: Sharing Economy Platform.

Marketing and Management of Innovations, 1, 11-25. [Google Scholar] [CrossRef]

Korcsmaros, E., Machova, R., Seben, Z., \& Feher, L. (2018). Slovakia after the Introduction of the Euro (overview of the period 2009-2011). Hradec Economic Days: Double-Blind Peer-Reviewed Proceedings Part I. of the International Scientific Conference: January 30-31, 2018. Hradec Kralove: Univerzita Hradec Kralove, 439-446. [Google Scholar] [CrossRef]

Maastrichti kriteriumok es teljesülesük. Retrieved from: [Link]

Machova, R., Veghova, K. (2013). Az Euró bevezetesenek hatasa a gazdasag versenykepessegere Szlovakiaban. Zborník medzinarodnej vedeckej konferencie UJS - 2013: «Nove výzvy vo vede a vo vzdelavaní» Sekcia ekonomických vied. Komarno: Univerzita J. Selyeho, 391-422.

Mihalcova, B., Gallo, P., \& Lukac., J. (2020). Management of Innovations in Finance Education: Cluster Analysis for OECD

Countries. Marketing and Management of Innovations, 1, 235-244. [Google Scholar] [CrossRef]

MNB. (2001). A Magyar Nemzeti Bank 2001. evrol szóló üzleti jelentese es eves beszamolója. Retrieved from [Link]

MTI-Eco. (2011). Bulgaria elhalasztja az ERM-2 tagsagról szóló targyalasok megkezdeset. Retrieved from[Link] 
NBS. Výmena slovenských bankoviek a slovenských pamätných mincí. Retrieved from [Link]

Origo. (2012). Bulgaria lemondott az euró bevezeteserol. Retrieved from [Link]

Papaspyrou, T. (2004). EMU strategies: Lessons from Greece in view of EU enlargement. Retrieved from [Link]

Polasek, W., \& Amplatz, C. (2003). The Maastricht Criteria and the Euro: Has the Convergence Continued? Journal of Economic Integration, 18(4), 661-688. [Google Scholar]

Privatbankar. (2013). Majd akkor lesz roman euró, amikor magyar?. Retrieved from [Link]

Rajnoha, R., Merkova, M., Dobrovic, J., \& Rózsa, Z. (2018). Business performance management and FDI: Key differences between foreign and domestic-owned firms-A case of Slovakia. Journal of Business Economics and Management, 19(1), 42-62. [Google Scholar] [CrossRef]

Treaty on European Union. (1992). Retrieved from [Link]

Verbeken, D., Rakic, D. (2019). History of economic and monetary union. Retrieved from LLink

Vovchak O. D., Rudevska V. I., Pohorila O. V. (2018). Challenges of inflation targeting in Ukraine: establishing the megaregulator. Financial and credit activities: problems of theory and practice, 1(24), P. 305-311. [CrossRef]

Zestos, G. K., \& Benedict, J. M. (2018). European Monetary Integration: A History. Encyclopedia of International Economics and Global Trade. [Google Scholar]

Еніко Корчмарош, Ph.D., Університет Дж. Сельє, Словаччина;

Рената Мачова, Ph.D., доцент, Університет Дж. Сельє, Словаччина;

Золтан Себен, Ph.D., Університет Дж. Сельє, Словаччина;

Тібор Зігмонд, Університет Дж. Сельє, Словаччина.

Управління регіональним інноваційним розвитком: критерії конвергенції Словаччини

Стаття присвячена аналізу особливостей та проблемам управління регіональним інноваційним розвитком. У 1979 році Європейською Спільнотою було впроваджено систему «Європейський механізм валютних курсів» 3 метою урегулювання коливань валютних курсів у країнах-членах $€ С$. Автори зазначили, що підписання Договору про вступ Словаччини та дев'яти інших країн до ЄС відбулось 16 квітня 2003 року в Афінах. Своєю чергою, підписання договору передбачало прийняття єдиної валюти (євро). У рамках статті автори проаналізували фактори, які сприяли економічному відновленню Словаччини ї̈ інноваційному розвитку за 10 років після введення єдиної валюти. У роботі представлено стислу характеристику єврозони та хронологічний порядок вступу країн до ЄС. У статті підлягають розгляду питання щодо загальних умов управління інноваційним розвитком країни та їх змін з введенням євро валюти в ЄС, та, зокрема, в Словаччині. Для перевірки тісноти зв'язку між середніми значеннями інфляції та дефіцитом державного бюджету, середнім значенням інфляції та державним боргом використано коефіцієнт кореляції Пірсона. Джерелом статистичних даних $є$ вебсайт Eurostat. Дане дослідження має низку обмежень. Зокрема, статистичні дані, представлені у базі даних Eurostat $\epsilon$ орієнтовними, тоді як, розглядаючи можливість приєднання окремої країни до ЄС, відповідальні органи використовують більш надійні дані. При цьому через відсутність статистичних даних щодо вартості словацької крони після вступу країни до ЄC, критерій ERM II, який відповідає за вступ країни до єврозони не може бути детально проаналізований. Наступним критерієм обмеженням $€$ можливі внесення коректив при обчисленні інфляцції та середніх номінальних довгострокових процентних ставок. Опускаючи критерії обмеження, автори прийшли до висновку, що Словаччина вчасно прийняла рішення щодо введення єдиної валюти євро до 1 січня 2009 року. Отримані результати засвідчили, що виходячи з рівня інфляції 2018 року, введення євро валюти у Словаччині було б неможливим, оскільки реальний рівень інфляції (2,5 відсотка) перевищує гранично допустимий (2,23 відсотка). Однак, опускаючи орієнтовний характер дослідження та не враховуючи значення ERM II, отримані результати можна вважати практично значущими.

Ключові слова: інноваційний розвиток, Словаччина, єдина валюта, рівень інфляції, дефіцит державного бюджету, державний борг. 